Tropical Journal of Pharmaceutical Research December 2016; 15 (12): 2579-2585

ISSN: $1596-5996$ (print); 1596-9827 (electronic)

(C) Pharmacotherapy Group, Faculty of Pharmacy, University of Benin, Benin City, 300001 Nigeria.

All rights reserved.

Available online at http://www.tjpr.org

Original Research Article

http://dx.doi.org/10.4314/tjpr.v15i12. 7

\title{
Gamma radiation effects on crude oil yield of some soybean seeds: Functional properties and chemical composition of glycine max-ataem-7 seeds
}

\author{
Yeşim Kara*, Havser Ertem Vaizoğullar and Ayşe Kuru \\ Department of Biology, Faculty of Science and Arts, Pamukkale University, Denizli, Turkey \\ *For correspondence: Email: eylul@pau.edu.tr; Tel: +90-258-2963669; Fax: +90-258-2963535 \\ Received: 9 January 2016 \\ Revised accepted: 29 October 2016
}

\begin{abstract}
Purpose: To investigate the crude oil yield of eight different varieties of soybean (Glycine max L.) seeds after gamma radiation, and also to evaluate the antimicrobial activity and the chemical composition of G. max-Ataem7.

Methods: The seeds were irradiated with doses of 0 (control), 100, 200, 300, 400 and 500 Gy gamma radiation. Irradiation was performed in a cesium (Ce137) source. Extraction of the seeds was done with Soxhlet apparatus using petroleum ether. Antimicrobial activity was determined by the standard disc diffusion method. The chemical composition of the extracts was elucidated using gas chromatographymass spectrometry (GS-MS)

Results: The highest crude oil yield was obtained at 300 Gy and and content of $35.09 \%$ in Ataem7 seeds. There was a decrease in the total content of chlorophyll in Mutant1 (M1) plants after gamma radiation. However, the level of carotenoid increased in M1 plants. Extracts of the G.max-Ataem7 demonstrated strong antibacterial activity against S. aureus ATCC 25923 and E.coli ATCC 25922. The major components of G.max-Ataem7 were linoliec acid (C18:2n6) and oleic acid (C18:1n9) with a content of 60.31 and $21.64 \%$, respectively.

Conclusion: The results show that irradiation of is also can be improved if treated with appropriate doses of irradiation.
\end{abstract}

Keywords: Gamma Rays; Soybean, Glycine max-Ataem-7, Oil yield, Chemical composition

Tropical Journal of Pharmaceutical Research is indexed by Science Citation Index (SciSearch), Scopus, International Pharmaceutical Abstract, Chemical Abstracts, Embase, Index Copernicus, EBSCO, African Index Medicus, JournalSeek, Journal Citation Reports/Science Edition, Directory of Open Access Journals (DOAJ), African Journal Online, Bioline International, Open-J-Gate and Pharmacy Abstracts

\section{INTRODUCTION}

Soybean (Glycine max L.) is a protein rich oil seed crop grown throughout the world. Soybean contains significant amounts of all the essential amino acids and fatty acids for humans, which are often used to prepare extracts or powders for medicinal use [1]. There is scientific attention on the health advantages of soybeans in both in vivo and in vitro experiments [2]. Therefore, plant breeding has gained importance especially soybean plants.
Radiation has been used effectively to cause suitable mutations for plant breeding improvement [3]. The percentage of spontaneous mutations is too low for breeding purposes in nature. Hence, chemical and physical mutagens can be used to encourage mutation [4]. Genetic variability is the most important requirement for effective crop development in terms of variant selection. Physical mutagens especially by using gamma-radiation, have been used by many researches for crop development [4]. 
Seed radiation is commonly used to implement a method to improve crop production, yield components and chemical composition. Some studies have investigated the effects of gamma radiation on soybean plants, including changes at the physicochemical levels. These effects include changes in the plant composition of chemical, crude oil yield and sensory [5].

The current investigation aims to explore scientifically the effects of gamma radiation on the crude oil yield of eight varieties of soybean seeds were studied, and the physiological effects, antimicrobial activity and chemical composition of the G.max-Ataem7 seed were investigated.

\section{EXPERIMENTAL}

\section{Materials}

The seeds were obtained from Izmir Aegean Agricultural Research Institute and the Antalya Western Mediterranean Agricultural Research Institute in 2011. The soybean seeds variety of Umut-2002, Ataem-7, Arısoy, Cinsoy, Nova, Üstün, Mitchell and Batem-Erensoy were used for the experiments. The irradiated and nonirradiated seeds were placed in sealed bags and were stored at room temperature $\left(20^{\circ} \mathrm{C}\right)$ without exposure to direct sunlight.

\section{Methods}

\section{Gamma radiation application}

The gamma radiation doses [0 (control), 100, 200, 300, 400 and $500 \mathrm{~Gy}$ ] were applied to the soybean seeds. Irradiation was performed in a cesium (Ce 137) Gammacell 3000 Elan source with a dose rate $\sim 9.75 \mathrm{~Gy} / \mathrm{min}(2900 \mathrm{Ci})$ in the Department of the Radiology at the Pamukkale University Faculty of Medicine. Irradiated and non-irradiated samples were stored at room temperature $\left(20^{\circ} \mathrm{C}\right)$.

\section{Determination of crude oil yield}

After the application of gamma radiation, about 4 $\mathrm{g}$ of crushed seeds were extracted with Soxhlet apparatus (GFL, SR1050 Inc) with petroleum ether being used as a solvent. The extraction was carried on for $6 \mathrm{~h}$ with $250 \mathrm{~mL}$ of solvent. The extracts were concentrated, and the solvent was removed under reduced pressure at $40{ }^{\circ} \mathrm{C}$ using a rotary evaporator (IKA RV-10, Germany) [6].

\section{Physiological effects of gamma radiation on M1 plant}

Twenty seeds were placed in plastic vials. Seeds were sown in a mixture of pet/vermiculture $(2: 1)$. Vials were placed in a greenhouse at the Plant Genetics and Agricultural Biotechnology Application and Research Center (BIYOM) at 20$25 \stackrel{\circ}{\circ} \mathrm{C}$ standard conditions. Seedling and root length was measured using a measuring tape (cm). The seedling and roots fresh weight was measured with precision scales $(\mathrm{g})$ (Precisa, XB $220 \mathrm{~A}$, Swiss). The seedling and roots fresh sample was dried in an oven at $70{ }^{\circ} \mathrm{C}$ for $48 \mathrm{~h}$ [7]. Dry matter qualitative determination was made following the methods laid out in [8].

\section{Photosynthetic pigment analysis (fresh weight)}

Photosynthetic pigments were determined using the Arnon method [7]. Chlorophyll was extracted from a similar position with regard to the leaves of ten plantlets. The optical density (OD) was measured using with a UV-VIS spectrophotometer (Optimum One Chebios, Italy) at $663 \mathrm{~nm}$ for chlorophyll-a, at $645 \mathrm{~nm}$ for chlorophyll-b and at $470 \mathrm{~nm}$ for carotenoid. The chlorophyll-a (Eq 1), chlorophyll-b (Eq 2), total chlorophyll (Eq 3) and carotenoid (Eq 4) concentrations were determined from the following equations [9].

Chl.a $(\mathrm{mg} / \mathrm{g})=(12.7 \times$ OD663 $-2.69 \times$ OD645) $\mathrm{V} /(1000 \mathrm{~W})$

Chl.b $(\mathrm{mg} / \mathrm{g})=(22.9 \times 0$ OD645 $-4.68 \times$ OD663)V/(1000 W)

Total Chl. $(\mathrm{mg} / \mathrm{g})=(20.2 \times 0 D 645+8.02 \times$ OD663) $\mathrm{V} /(1000 \mathrm{~W})$

Car. $(\mathrm{mg} / \mathrm{mL})=[4,07 \times$ OD450- $(0,0435 \times$ $\mathrm{kla}+0,367 \times \mathrm{klb})]$

where $\mathrm{V}$ is the total volume of acetone extract $(\mathrm{ml})$ and $\mathrm{W}$ is the fresh weight $(\mathrm{g})$ of the sample.

\section{Antimicrobial activity of G.max-Ataem7 extracts}

Staphylococcus aureus ATCC 25923, Escherichia coli ATCC 25922 and Pseudomonas aeruginosa ATCC 27853 strains were obtained from the American Type Culture Collection (ATCC) and Micrococcus luteus NRRL B4375 was obtained from the Northern Regional Research Laboratory (NRRL). The bacteria were cultured in Nutrient Broth (NB) (Difco) and were then incubated at $37 \pm 0.1{ }^{\circ} \mathrm{C}$ for $24-48 \mathrm{~h}$. The 
antimicrobial activity of the extracts were assayed using the standard disc diffusion method [10]. Inhibition zone was measured using a measuring tape $(\mathrm{mm})$. Discs of petroleum ether (Merck) were used as negative controls. Discs of ampicillin (10 $\mu \mathrm{g}$, Oxoid), Penicillin (10 U, Oxoid) and Gentamycin (10 $\mu \mathrm{g}$, Oxoid) were used as positive controls.

\section{Gas chromatography-mass spectrometry (GC-MS)}

The seed oil was analyzed using GS-MS. The GS-MS analyses were carried out on an Agilent 7890 A GS-MS equipped with a HP-88 silica column $(100 \mathrm{~m} \times 0.250 \mathrm{~mm}$, film thickness 0.20 $\mu \mathrm{m})$; the oven temperature was held at $60{ }^{\circ} \mathrm{C}$ for $1 \mathrm{~min}$ and was then programmed to $175^{\circ} \mathrm{C}$ at 13 ${ }^{\circ} \mathrm{C}$ and programmed their temperature to $215{ }^{\circ} \mathrm{C}$ at $4 \stackrel{\circ}{\circ} \mathrm{C} / \mathrm{min}$ [11]. The percentage oil composition of the extracts were determined using the MSDChem computer programme.

\section{Statistical analysis}

The experiments were carried out in triplicate and three measurements were conducted for each replicate. The data were analyzed by analysis of variance (ANOVA) using SAS software (Inc. Chicago, IL, USA, 1988). Statistical analysis was carried out using SAS computer software. Significant differences between values were determined using Duncan's Multiple Range test. $P<0.05$ was considered statistically significant.

\section{RESULTS}

The effect of gamma radiation on the crude oil yield of eight different varieties of soybean (Glycine max L.) seeds is shown in Figure 1. The crude oil yields of $G$. max seeds were determined to be between 13.11 and $35.09 \%$ for Batem-Erensoy and Ataem-7, respectively. The highest crude oil yield was obtained at 300 Gy dose in Ataem-7 seeds.

The physiological effects of G. max-Ataem7 (the variety which showed the highest oil yield) were studied in terms of all irradiation doses. This study has shown that gamma radiation exerts a significant inhibitory influence on the growth of M1 generation plants (Table 1). The highest plant height was related to control plants and a dose of $100 \mathrm{~Gy}$, while the lowest plant height was related to a dose of 500 Gy.

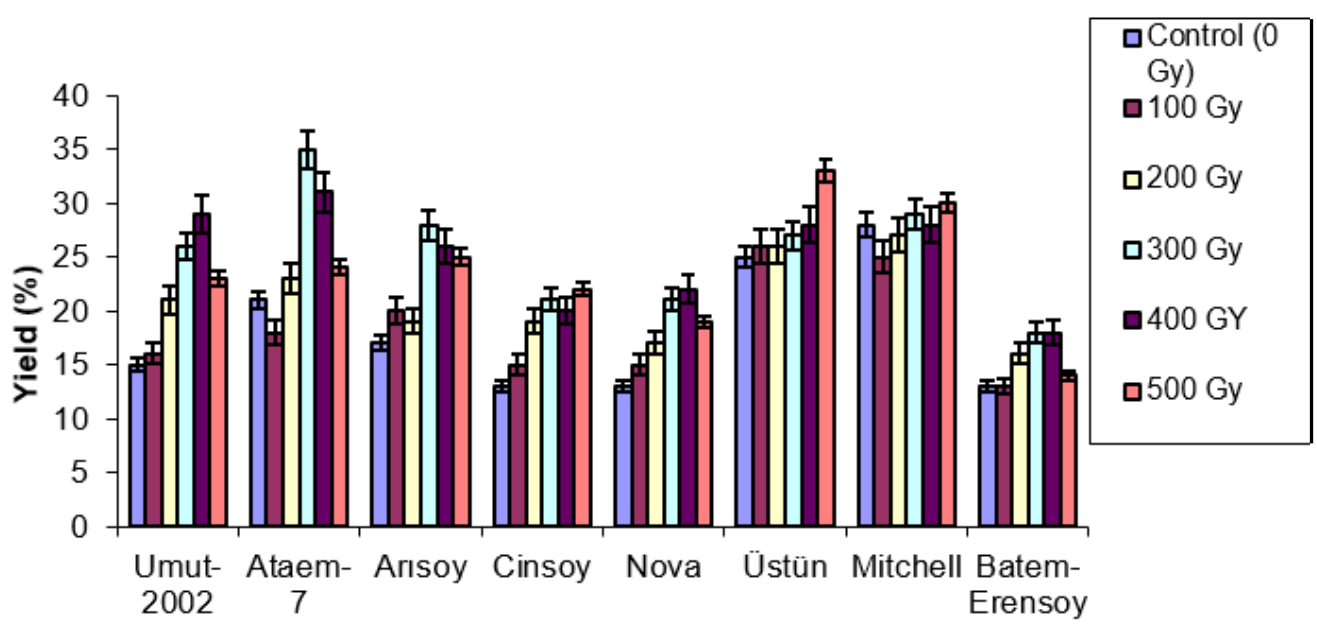

Figure 1: Effects of gamma radiation on crude oil yield of Glycine max seeds (dry matter, \%)

Table 1: Growth properties of G. max-Ataem7 M1 generation

\begin{tabular}{lccccccc}
\hline Variable & $\begin{array}{c}\text { Seedling } \\
\text { length } \\
\text { (mm) }\end{array}$ & $\begin{array}{c}\text { Root } \\
\text { length } \\
\text { (mm) }\end{array}$ & $\begin{array}{c}\text { Number of } \\
\text { leaves } \\
\text { (no/plant) }\end{array}$ & $\begin{array}{c}\text { Seedling } \\
\text { fresh } \\
\text { weight (g) }\end{array}$ & $\begin{array}{c}\text { Seedling } \\
\text { dry } \\
\text { weight (g) }\end{array}$ & $\begin{array}{c}\text { Rooth } \\
\text { fresh } \\
\text { weight (g) }\end{array}$ & $\begin{array}{c}\text { Rooth dry } \\
\text { weight (g) }\end{array}$ \\
\hline Control & 160 & 3 & 9 & 4.61 & 4,10 & 1,39 & 1,15 \\
100 Gy & 120 & 5 & 7 & 4,01 & 3,66 & 1,24 & 0,95 \\
$\mathbf{2 0 0}$ Gy & $60^{\mathrm{a}}$ & 4 & 3 & 2,89 & 2,09 & $1,03^{\mathrm{b}}$ & $0,61^{\mathrm{b}}$ \\
$\mathbf{3 0 0} \mathbf{~ G y}$ & $60^{\mathrm{a}}$ & 3 & 2 & 2,52 & 1,94 & $0,56^{\mathrm{a}}$ & $0,43^{\mathrm{b}}$ \\
$\mathbf{4 0 0} \mathbf{G y}$ & 50 & $2^{\mathrm{a}}$ & 2 & $2,13^{\mathrm{b}}$ & $1,68^{\mathrm{a}}$ & 0,28 & 0,10 \\
$\mathbf{5 0 0} \mathbf{~ G y}$ & 40 & $1^{\mathrm{b}}$ & 2 & $2,10^{\mathrm{b}}$ & $1,53^{\mathrm{b}}$ & 0,11 & 0,04 \\
\hline
\end{tabular}

Significant at $p<0.05$ and 0.01 , respectively; NS: not significant at $p<0.05$ 
The effects of gamma radiation on the chlorophyll-a, chlorophyll-b, total chlorophyll and carotenoid pigments of $G$. max Ataem-7 are shown in Figure 2. When compared to the controls, decreases in the total amounts of chlorophyll was detected in M1 plants. On the other hand, carotenoid amounts were increased in G. max Ataem-7 M1 plants.

The antimicrobial activity of G. max-Ataem7 extracts were determined against two Grampositive $[\operatorname{Gr}(+)]$ and two Gram-negative $[\operatorname{Gr}(-)]$ bacteria (Table 2). All doses extracts of the $G$. max-Ataem7 demonstrated antibacterial activities against the S. aureus ATCC 25923, E.coli ATCC 25922 and M. luteus NRRL B-4375.

Table 3 provides a summary of fatty acid composition and the percentage of saturated and unsaturated fatty acids. Fifteen components of the extracts were obtained by soxhlet extraction and these were detected using GC-MS analytical methods. It was determined that, linoliec acid $(\mathrm{C} 18: 2 \mathrm{n} 6)$ and oleic acid (C18:1n9) were the

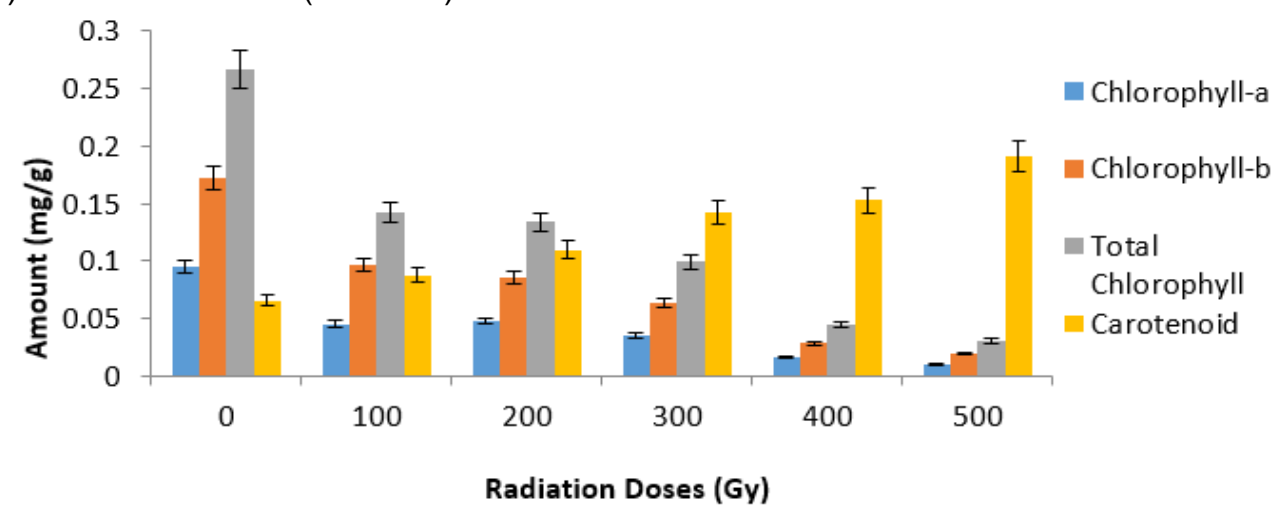

Figure 2: Effect of gamma radiation on photosynthetic pigments of G. max-Ataem7 M1 generation major components, with an average of 60.31 and $21.64 \%$, respectively.

\section{DISCUSSION}

The effects of gamma radiation on some of the properties of many plants and seeds have been investigated by researchers [12-14]. In this study, the crude oil yield of all extracts of G. max were positively affected by gamma rays.

Our results are supported by previous published studies that report an increase in oil production subsequent to gamma irradiation in several plant species [15]. However, Dixit et al [13] determined that the nutritional features i.e. fatty acids, protein and the oil of soybean seeds, remained stable after gamma radiation.

It has been noticed that environmental conditions can affect seed composition in terms of such features as oil and protein content.

Table 2: Antimicrobial activity of G. max-Ataem7 extracts

\begin{tabular}{|c|c|c|c|c|c|}
\hline \multirow{4}{*}{ Extract } & \multirow[b]{4}{*}{$\begin{array}{c}\text { Concentration } \\
\text { ( } \mu \mathrm{l} / \mathrm{disc})\end{array}$} & \multicolumn{4}{|c|}{ Inhibition zone diameter (mm) } \\
\hline & & \multicolumn{4}{|c|}{ Microorganism } \\
\hline & & \multicolumn{2}{|c|}{$\operatorname{Gr}(+)$} & \multicolumn{2}{|r|}{$\operatorname{Gr}(-)$} \\
\hline & & $\begin{array}{c}\text { M. luteus } \\
\text { NRRL B-4375 }\end{array}$ & $\begin{array}{c}\text { S. aureus } \\
\text { ATCC } 25923\end{array}$ & $\begin{array}{l}\text { E. coli } \\
\text { ATCC } \\
25922\end{array}$ & $\begin{array}{l}P . \text { aeruginosa } \\
\text { ATCC } 27853\end{array}$ \\
\hline $\mathrm{C}$ & $10 \mu \mathrm{l}$ & $8 \pm 0.5$ & $9 \pm 0.5$ & $7 \pm 0.5$ & - \\
\hline $\mathrm{E} 1$ & $10 \mu \mathrm{l}$ & $9 \pm 0.5$ & $10 \pm 0.5$ & $7 \pm 1.5$ & - \\
\hline E2 & $10 \mu \mathrm{l}$ & $9 \pm 1$ & $11 \pm 1$ & $8 \pm 0.5$ & - \\
\hline E3 & $10 \mu \mathrm{l}$ & $10 \pm 1.5$ & $12 \pm 1.5$ & $8 \pm 1$ & - \\
\hline E4 & $10 \mu \mathrm{l}$ & $11 \pm 0.5$ & $13 \pm 1$ & $8 \pm 1.5$ & - \\
\hline E5 & $10 \mu \mathrm{l}$ & $11 \pm 1$ & $14 \pm 1.5$ & $9 \pm 0.5$ & - \\
\hline \multicolumn{6}{|c|}{$\begin{array}{l}\text { Reference } \\
\text { antibiotics }\end{array}$} \\
\hline$A$ & $10 \mu \mathrm{g}$ & 28 & NT & 21 & NT \\
\hline$P$ & $10 U$ & 29 & 30 & 18 & NT \\
\hline $\mathrm{G}$ & $10 \mu \mathrm{g}$ & NT & NT & NT & 15 \\
\hline
\end{tabular}


Table 3: Chemical compositions of G.max-Ataem7 extracts in GC-MS methods

\begin{tabular}{|c|c|c|c|c|c|c|c|c|c|c|}
\hline & & Compound & Structure & $\mathbf{R t}$ & $\begin{array}{l}\text { C } \\
(\%)\end{array}$ & $\begin{array}{l}\text { E1 } \\
(\%)\end{array}$ & $\begin{array}{l}\text { E2 } \\
(\%)\end{array}$ & $\begin{array}{l}\text { E3 } \\
(\%)\end{array}$ & $\begin{array}{l}\text { E4 } \\
(\%)\end{array}$ & $\begin{array}{l}\text { E5 } \\
(\%)\end{array}$ \\
\hline \multirow{7}{*}{ 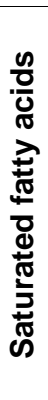 } & 1 & $\begin{array}{l}\text { Lauric acid } \\
\text { ME* }^{*}\end{array}$ & $(\mathrm{C} 12: 0)$ & 27,3 & - & - & - & - & - & - \\
\hline & 2 & Myristic Acid ME* & (C14:0) & 30,4 & 0,36 & 0,35 & 0,12 & 0,24 & 0,23 & 0,21 \\
\hline & 3 & Palmitic acid $\mathrm{ME}^{*}$ & (C16:0) & 34,5 & 14,12 & 14,13 & 13,63 & 15,48 & 15,21 & 15,26 \\
\hline & 4 & $\begin{array}{l}\text { Heptadecanoic } \\
\text { (Margaric) acid } \mathrm{ME}^{*}\end{array}$ & (C17:0) & 36,5 & 0,09 & 0,09 & 0,14 & 0,02 & 0,02 & 0,01 \\
\hline & 5 & Stearic Acid $\mathrm{ME}^{*}$ & (C18:0) & 39,1 & 3,82 & 3,71 & 3,14 & 3,31 & 3,28 & 3,51 \\
\hline & 6 & Arachidic Acid ME* & (C20:0) & 43,3 & 0,45 & 0,33 & 0,29 & 0,11 & 0,11 & 0,09 \\
\hline & 7 & $\begin{array}{l}\text { Pentadecanoic } \\
\text { (Pentadecyclic) Acid } \\
\text { ME* }^{*}\end{array}$ & $(\mathrm{C} 15: 0)$ & 32,3 & - & - & - & - & - & - \\
\hline \multirow{8}{*}{ 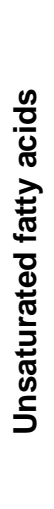 } & 8 & Myristoleic Acid ME* & (C14:1) & 31,8 & - & - & - & - & - & - \\
\hline & 9 & Palmitoleic acid $\mathrm{ME}^{*}$ & (C16:1) & 35,5 & 0,14 & 0,13 & 0,07 & 0,33 & 0,21 & 0,19 \\
\hline & 10 & $\begin{array}{l}\text { Oleic acid } \\
\text { ME* }^{*}\end{array}$ & (C18:1n9) & 40,3 & 21,03 & 21,02 & 15,48 & 21,64 & 21,27 & 21,14 \\
\hline & 11 & $\begin{array}{l}\text { cis-11eicosenoic acid } \\
\text { ME* }^{*}\end{array}$ & (C20:1) & 44,9 & - & - & - & - & - & - \\
\hline & 12 & Linoliec Acid $\mathrm{ME}^{*}$ & $(\mathrm{C} 18: 2 \mathrm{n} 6)$ & 42,1 & 54,78 & 54,80 & 60,31 & 53,38 & 53,34 & 53,72 \\
\hline & 13 & g-linolenic acid $\mathrm{ME}^{*}$ & $(\mathrm{C} 18: 3 n 6)$ & 44,2 & 4,08 & 4,63 & 6,03 & 4,75 & 4,71 & 4,03 \\
\hline & 14 & $\begin{array}{lr}\text { cis } & 11,14- \\
\text { eicosadienoic } & \text { acid } \\
M^{*} & \end{array}$ & $(\mathrm{C} 20: 2)$ & 48,3 & 0,20 & 0,21 & 0,31 & 0,38 & 0,33 & 0,35 \\
\hline & 15 & $\begin{array}{l}\text { EPA } \\
\text { (Eicosapentaenoic } \\
\text { acid) } \mathrm{ME}^{*}\end{array}$ & $(\mathrm{C} 20: 5 \mathrm{n} 3)$ & 53,3 & 0.74 & 0,63 & 0,42 & 0.10 & 0,10 & 0,10 \\
\hline
\end{tabular}

Major differences in the protein content of the soybean species in different climatic conditions have been observed [16]. However, the information on the chemical composition and antimicrobial activity of soybean seeds exposed to gamma radiation was limited. In general, seedling length of M1 plants was decreased by gamma radiation while increase in the dose of gamma rays. The stimulating affect of low doses of gamma radiation on plant development may be due to the stimulation of cell elongation or cell division involving the modification of metabolic processes that affect the synthesis of nucleic acids [12].

On the other hand, one study has reported that there is a reduction in the number of plant leaves and branches of plants irradiated with low doses of gamma rays [17]. In our study, it has been found that gamma rays have a negative effect on root and leaf growth. Similarly, Alikamanoğlu et al [14] found that leaf number of Pawlonia tomentosa decreased according to the applied dose (10 and 25 Gy) and this physiological damage in $\mathrm{M} 1$ generation caused by radiation.

Aparna et al [18] also showed that higher doses of gamma radiation have a negative effect on plant growth. Similarly, there are some reports which indicate that higher doses of gamma radiation are usually inhibitory [4], whereas lower doses are sometimes stimulatory [16].

Afify and Shousha [19] reported that gamma radiation caused molecular changes. Hence, it is presumed that molecular compositions caused changes in secondary structure, especially at higher dose levels.

The antimicrobial activity of extracts has been evaluated in vitro against four bacterial species (Table 2). Compared to reference antibiotics, extracts of the G. max-Ataem7 showed antimicrobial activities particularly against $\mathrm{Gr}(+)$ bacteria. However, all of extracts showed no antimicrobial activities against $P$. aeruginosa ATCC 27853. The antimicrobial activity of the soybean plants were reported [20,21]. Similarly, the methanol extracts of $G$. max showed antibacterial activity against $S$. aureus [20,21]. On the other hand, methanol extracts of $G$. max showed no antibacterial activity against $P$. aeruginosa [20] and $P$. fluorescens [21].

It was determined that, linoleic acid, oleic acid and palmitic acid were the major components with an average of $60.31,21.64$ and $15.48 \%$, respectively. Azcan et al [22] obtained results for 
the oil content of thirty soybean seed varieties, and determined that the average percentage of linoleic and oleic acid content in the Ataem7 was $51.25 \%$ and $27.34 \%$, respectively. The highest linoleic acid percentage was observed in 200 Gy irradiated seed $(60.31 \%)$ as compared to a control (54.78\%). Palmitoleic acid (C16:1) and cis 11-14 eicosadienoic acid (C20:2) were shown to increase fatty acid percentage after being dosed with gamma radiation.

lonizing radiation might affect the quality of oils by increasing the degree of oxidation. It may also present active molecules such as free radicals, which may start chemical reactions that might also result in the souring of oil and fats. The radiation of lipid stimulates the production of free radicals which react with oxygen, and are responsible for the formation of carbonyl groups and the modification sensorial and nutritional features of foods.

lonizing radiations affect the fatty acid composition of natural oils, and the lipid peroxide formation as a result indicates that the peroxide value of oils and fats would increase with irradiation [23]. A study of the effect of radiation involving gamma radiation (0.5, 1.0 and $1.5 \mathrm{kGy})$ on the lipids present in different plant nuts, revealed that the lipid extracted from the seeds have peroxide, anisidine and free fatty acid values higher than in non-irradiated samples [15].

\section{CONCLUSION}

The results of this study demonstrate that gamma radiation has a generally positive effect on the crude oil yield of $G$. max seeds. The results showed that the highest crude oil yield $(35.09 \%)$ was obtained from a dose of $300 \mathrm{~Gy}$ applied to Ataem-7 soybean seeds. Similarly, the antibacterial activity of G. max-Ataem7 extracts showed high activity in terms of $\mathrm{Gr}(+)$ bacteria, especially $S$. aureus ATCC 25923 . Our results may suggest that gamma radiation application of G.max-Ataem7 seeds was effective in substantially improving oil yield and antimicrobial activity.

\section{DECLARATIONS}

\section{Acknowledgement}

This study was supported by The Scientific Research Projects Coordination Department of Pamukkale University, Project No: 2012FBE013. Thanks to the Pamukkale University Plant
Genetics and Agricultural Biotechnology Application and Research Center (PAU BIYOM).

\section{Conflict of Interest}

No conflict of interest associated with this work.

\section{Contribution of Authors}

The authors declare that this work was done by the authors named in this article and all liabilities pertaining to claims relating to the content of this article will be borne by them.

\section{Open Access}

This is an Open Access article that uses a funding model which does not charge readers or their institutions for access and distributed under the terms of the Creative Commons Attribution License (http://creativecommons.org/licenses/by 14.0) and the Budapest Open Access Initiative (http://www.budapestopenaccessinitiative.org/rea d), which permit unrestricted use, distribution, and reproduction in any medium, provided the original work is properly credited.

\section{REFERENCES}

1. Afify AMR, Rashed MM, Mahmoud EA and El-Beltagi HS. Effect of Gamma Radiation on Protein Profile, Protein Fraction and Solubility's of Three Oil Seeds: Soybean, Peanut and Sesame. Not Bot Horti Agrobo 2011; 39(2): 90-98.

2. Thanekar SKS, Ramachanhandra YL, Udgire $M$. Extraction, isolation, and antimicrobial activity of crude and purified ferritin extract from seeds of soyabean (Glycine max) L. Merr. Sch Acad J Pharm 2014; 3(2):9799.

3. Ifeanyichukwu OO, Gabriel I, Murty S, Kambhampati. Ecophysiological Effects of Nitrogen on Soybean (Glycine max L. Merr.). Open J Soil Sci. 2014; 4: 357365.

4. Mohajer S, Taha RM, Lay MM, Esmaeili AK, Khalili M. Stimulatory Effects of Gamma Irradiation on Phytochemical Properties, Mitotic Behaviour, and Nutritional Composition of Sainfoin (Onobrychis viciifolia Scop.). The Sci World J. 2014; 1-9.

5. Atak Ç, Alikamanoğlu S, Açık L, Canbolat Y. Induced of plastid mutations in soybean plant (Glycine max. L. Merrill) with gamma radiation and determination with RAPD. Mut Res. 2004; 556: 35-44.

6. Sabzalian M, Saeidi G, Mirlohi A. Oil Content and Fatty Acid Composition in Seeds of Three Safflower Species. J Am Oil Chem Soc 2008; 85:717-721.

7. Arnon DI. Copper enzymes in isolated chloroplasts, polyphenol oxidase in Beta vulgaris L. Plant Phy. 1949; 24: 1-15.

Trop J Pharm Res, December 2016; 15(12): 2584 
8. Dalaly B. and Al-Hakim S. Food Analysis. Department of Book House for printing and publishing. University of Mosul Arabic Version. Iraq. Food Analysis. Books house for printing and publishing, Mosul University, Iraq. 1987.

9. Lichtenthaler HK, Wellburn AR. Determinations of total carotenoids and chlorophylls $a$ and $b$ of leaf extracts in different solvents. Biochem Soc Trans 1983; 603,591592.

10. Collins CH. Microbiological Methods. (In: Lyne, P.M., Grange, J.M., Seventh ed. Butterworths, London), 1995; 493.

11. Bardakçı B, Seçilmiş Canbay H. Determination of Fatty Acid, $\mathrm{C}, \mathrm{H}, \mathrm{N}$ and Trace Element Composition in Grape Seed by GC/MS, FTIR. Elemental Analyzer and ICP/OES. SDU J Sci (E-Journal) 2011; 140-148.

12. Pitirmovae MA. Effect of gamma rays and mutagens on barley seeds. Fiziol Res 1979; 6:127-131.

13. Dixit AK, Kumar V, Rani A, Manjaya JG, Bhatnagar D. Effect of gamma irradiation on lipoxygenases, trypsin inhibitor, raffinose family oligosaccharides and nutritional factors of different seed coat colored soybean (Glycine max L.). Rad Phy Chem. 2011; 80:597-603.

14. Alikamanoglu S, Yaycılı O, Atak $C$ and Rzakoulieva A. Effect of magnetic field and gamma radiation on Pawlonia tomentosa tissue. Biotech \& Biotech Equip 2007; 21: 49-53.

15. Sattar A, Ahmad M, Hussain A, Khan I. Light induced oxidation of nut oils. Die Nahrung 1989; 33:213-215.

16. Vasconcelos IM, Campello CC, Oliveira JTA, Carvalho AFU, Souza DOB, Maia FMM. Brazilian soybean Glycine max (L.) Merr. cultivars adapted to low latitude regions: seed composition and content of bioactive proteins. Brazilian J Bot 2006; 29: 4.

17. Banerji BK, Datta SK. Gamma ray induced flower shape mutation in Chrysanthemum CV. Jaya J Nucl Agric Biol 1992; 21: 73-79.

18. Aparna M, Chaturvedi A, Sreedhar M, Kumar DP, VenuBabu $P$ and Singhal RK. Impact of gamma rays on the seed germination and seedling parameters of Groundnut (Arachis Gypogaea L.). Asian J Exp Biol Sci 2013; 4(1): 61-68.

19. Afify AMR and Shousha MA. Effect of low-dose irradiation on soybean protein solubility, trypsin inhibitor activity and protein patterns separated by polyacrylamide gel electrophoresis. J Agric Food Chem 1988; 36(4): 810-813.

20. Gladys INU, Antibacterial effects of methanolic extracts of soybean (Glycine max). Time J Bio Sci Tech 2015; 3(1):41-46.

21. Arora M, Singh S, Kaur R. Phytochemical analysis, protein content \& antimicrobial activities of selected samples of Glycine max Linn. Int J Res Eng Tech 2013; 2 (11):570-574

22. Azcan N, Hoşhün EZ, Güvenir B, Berberoğlu MA, Kara $M$. Soya yağı ekstraksiyonu, yağın kompozisyonu ve protein veriminin belirlenmesinde yöntem karşılaştırılması. 7. Ulusal Kimya Mühendisliği Kongresi, Eskişehir. 2006.

23. Victroria A, Corne AVJ, Hamilton JTG, Stevenson MH. Detection of 2-dodecylcyclobutanone in radiationsterilized chicken meat stored for several years. Int $J$ Food Sci Tech 1992; 27: 691-696. 